\title{
ANTESEDEN MINAT BERKUNJUNG KEMBALI WISATAWAN SPIRITUAL DI BALI \\ (THE ANTECEDENT OF SPIRITUAL TOURIST REVISIT INTENTION IN $B A L I)$
}

\author{
Holil Pujiyati ${ }^{1}$ \\ I Putu Gde Sukaatmadja ${ }^{2}$
} ${ }^{1,2}$ Fakultas Ekonomi Dan Bisnis, Universitas Udayana (Unud), Bali, Indonesia
email : holilpujiyati357@gmail.com

\begin{abstract}
ABSTRAK
Bali merupakan daerah tujuan wisata (DTW) primadona di Indonesia, tingginya kunjungan wisatawan merupakan peluang besar untuk meningkatkan revisit intention pada pariwisata spiritual Bali. Penelitian ini bertujuan unuk mengetahui pengaruh motivasi wisata spiritual, service quality, dan customer experience guna meningkatkan revisit intention pada wisatawan spiritual di Bali. Berdasarkan tingkat kunjungan wisatawan pada masing - masing kabupaten dan branding pariwisata spiritual, penelitian ini dilakukan di Kabupaten/Kota Tabanan, Badung, Gianyar, dan Karangasem dengan responden 50 orang wisatawan domestik dan 50 orang wisatawan mancanegara. Metode pengumpulan data menggunakan penyebaran kuesioner. Teknik analisis yang digunakan pada penelitian ini yaitu statistik deskriptif, statistik inferensial, analisis jalur, dan uji asumsi klasik yang terdiri atas uji normalitas, uji multikolinieritas, dan uji heteroskedastisitas serta uji sobel. Hasil penelitian menunjukkan motivasi wisata spiritual berpengaruh positif dan signifikan terhadap customer experience, service quality berpengaruh positif dan ssignifikan terhadap customer experience, motivasi wisata spiritual berpengaruh positif dan signifikan terhadap revisit intention, service quality berpengaruh positif dan signifikan terhadap revisit intention.
\end{abstract}

Kata kunci : motivasi wisata spiritual, service quality, customer experience, revisit intention.

\begin{abstract}
Bali is a prima donna tourist destination (DTW) in Indonesia, the high level of tourist visits is a great opportunity to increase revisit intention on Balinese spiritual tourism. This study aims to determine the effect of spiritual tourism motivation, service quality, and customer experience to increase revisit intention for spiritual tourists in Bali.Based on the level of tourist visits to each - massing districts and spiritual tourism branding, this research was conducted in Tabanan, Badung, Gianyar, and Karangasem Regencies with respondents of 50 domestic tourists and 50 foreign tourists. Methods of collecting data through questionnaires. The analysis technique in this study is descriptive statistics, inferential statistics, path analysis, and classic assumption tests which consist of normality test, multicollinearity test, and heteroscedasticity test and sobel test. The results showed that the motivation of spiritual tourism has a positive and significant effect on customer experience, service quality has a positive and significant effect on customer experience, spiritual tourism motivation has a positive and significant effect on revisit intention, service quality has a positive and significant effect on revisit intention.
\end{abstract}

Keywords : spiritual tourism motivation, service quality, customer experience, revisit intention 


\section{PENDAHULUAN}

Bali merupakan daerah tujuan wisata (DTW) primadona di Indonesia, dimana setiap tahunnya tingkat kunjungan wisatawan meningkat baik wisatawan domestik maupun mancanegara (Tabel 1). Tingginya kunjungan wisatawan ini merupakan peluang besar untuk meningkatkan revisit intention pada pariwisata Bali. Minat berkunjung ulang (revisit intention) diambil dari teori minat beli ulang terhadap suatu produk, sehingga dalam beberapa kategori minat berkunjung dapat diaplikasikan terhadap minat beli. Minat adalah dorongan untuk memotivasi seseorang melakukan tindakan (Putra dkk., 2015)

Menurut Miller et al., (2015) minat membeli ulang diartikan sebagai purchase intention yaitu keinginan yang kuat untuk membeli kembali, purchase intention adalah keadaan mental seseorang yang mencerminkan rencana untuk melakukan beberapa tindakan dalam jangka waktu tertentu. Penerapan dalam riset terhadap pengertian purchases intention adalah pelanggan melakukan pembelian kembali pada waktu mendatang sebagai respon langsung dari perilaku paska pembelian dalam jangka waktu tertentu. Purchases intention hubungannya dengan kunjungan wisatawan dalam pembelian jasa pariwisata disebut sebagai revisit intention.

Bali memiliki potensi besar untuk mengembangan wisata spiritual sebab, Bali merupakan pulau yang unik penuh dengan keragaman disebut pula sebagai Bali Dwipa, Pulau Dewata, dan Pulau Pariwisata menjadi kekuatan untuk mengembangkan wisata spiritual. Pariwisata spiritual dikemukakan oleh Bali Travel News (2008) (Sukaatmadja dkk., 2017) merupakan salah satu kegiatan wisata minat khusus, yakni perjalanan wisata menuju tempat - tempat suci untuk melaksanakan kegiatan spiritual berupa sembahyang, yoga, meditasi, konsentrasi, dekonsentrasi, dan istilah lainnya sesuai dengan agama dan kepercayaan masing masing. Pariwisata spiritual bukan fenomena baru di Bali yoga, meditasi, dan sebagainya yang termasuk dalam jasa pariwisata spiritual sudah ada sejak dulu, namun keberadaan pariwisata spiritual ini baru diperhitungkan beberapa tahun terakhir.

Tabel 1.

Kunjungan Wisatawan Domestik dan Mancaranegara di Bali 2013 - 2017

\begin{tabular}{ccc}
\hline \multirow{2}{*}{ Tahun } & Domestik & Mancanegara \\
\cline { 2 - 3 } & Total (Jiwa) & Total (Jiwa) \\
\hline 2013 & 6.976 .536 & 3.278 .598 \\
2014 & 6.394 .307 & 3.766 .638 \\
2016 & 7.147 .100 & 4.001 .835 \\
2017 & 8.643 .680 & 4.927 .937 \\
\hline
\end{tabular}

Sumber : $\quad$ https://bali.bps.go.id/statictable/2018/02/09/29/kunjungan-wisatawandomestik-ke-bali-per-bulan-2004-2016.html (Diakses 16 Oktober 2018) https://bali.bps.go.id/2018/02/09/28/jumlah-wisatawan-asing-ke-bali-danindonesia-1969-2017.html (Diakses 16 Oktober 2018)

Mengembangkan pariwisata berbasis spiritual memiliki daya tarik tersendiri bagi wisatawan yang tidak hanya ingin berlibur melainkan ingin mendapatkan kedamaian batin. Motivasi wisata spiritual merupakan kandidat utama pengembangan pasar dan strategi diversifikasi yang menargetkan minat berkunjung (Haq et al., 2015). Menurut Willson \& Suhud (2016) motivasi wisata spiritual mampu menumbuhkan minat berkunjung kembali. Motivasi wisata spiritual 
sebagai sarana untuk meningkatkan minat dan tingkat kunjungan wisatawan (Nashuddin, 2016)

Bali memiliki atraksi laut yang terhampar luas, tempat suci, dan warisan budaya yang begitu banyak sebagai potensi dalam merebut pasar baru dengan kebutuhan spiritual. Keberadaan sumber pendukung serta atraksi yang tersedia berarti Bali sebagai destinasi siap memenuhi kebutuhan pariwisata spiritual dengan segala aspek pendukungnya termasuk kualitas pelayanan. Kualitas pelayanan menurut Kotler dan Keller (2015) merupakan seluruh ciri dan sifat suatu produk atau layanan yang berpengaruh pada kemampuan memuaskan kebutuhan yang dinyatakan atau tersirat. Pada jasa, diperlukan layanan yang membuat pelanggan senang dan puas. Mengacu pada layanan tersebut tingkat kualitas layanan yang baik akan selalu dilihat dan diukur pada sisi konsumen serta pemenuhan kepuasan layanan yang diterima. Kualitas mempengaruhi kesan konsumen terhadap produk dan kesan ini berdampak pada proses dari kualitas yang diharapkan terhadap kualitas yang dirasakan (Prabaharan 2015). Semakin tinggi kualitas layanan, semakin meningkat tingkat kunjungan (Sopyan, 2015). Pelanggan yang puas menimbulkan berpengaruh positif terhadap perilaku setelah pembelian, seperti minat beli kembali, jumlah pembelian, jumlah merek yang dibeli, dan lain sebagainya. Bentuk loyalitas customer kaitannya dengan kunjungan wisatawan dan pembelian jasa pariwisata disebut revisit intention.

Komponen pendukung yang ada pada destinasi sekaligus melihat kemungkinan sejumlah aktivitas yang dapat dilakukan, Sapta Pesona yang harus direvitalisasi kembali, dalam rangka memperoleh nilai tersendiri terhadap pengalaman pribadi wisatawan (Wendri, 2016). Wisatawan yang sudah pernah melakukan kunjungan pariwisata spiritual di Bali tentu memiliki penilaian tersendiri akan destinasi yang membuat wisatawan nantinya akan melakukan kunjungan kembali atau merekomendasikan kepada orang lain.

Pra - survei dilakukan untuk mendukung penelitian ini. Berdasar 21 responden yang mengisi kuesioner menjawab berbeda - beda destinasi pariwisata spiritual yang pernah dikunjungi namun masih di daerah Bali, 95,2 persen responden menjawab telah beberapa kali melakukan kunjungan pariwisata spiritual, 85,7 persen responden menjawab akan melakukan kunjungan kembali pada destinasi pariwisata spiritual yang telah mereka kunjungi, dan 87 persen responden menjawab pelayanan yang diberikan saat melakukan aktivitas pariwisata spiritual baik.

Berdasarkan Tabel 1, Tabel 2, dan potensi Bali yang belum dioptimalkan dalam pengelolaan pariwisata spiritual, serta hasil pra - survei menunjukkan adanya research gap pada variabel revisit intention. Upaya yang bisa dilakukan untuk menarik minat berkunjung kembali yaitu memberikan makna penuh mengenai motivasi wisata spiritual saat wisatawan melakukan aktivitas pariwisata, meningkatkan service quality sehingga wisatawan mendapat experience tak terlupakan yang dapat menciptakan minat berkunjung kembali. 
Tabel 2.

Kunjungan Wisatawan Masing - Masing Kabupaten di Bali 2011 - 2015

\begin{tabular}{|c|c|c|c|c|c|c|}
\hline \multirow{2}{*}{ No } & \multirow{2}{*}{ Kabupaten/Kota } & 2011 & 2012 & 2013 & 2014 & 2015 \\
\hline & & \multicolumn{5}{|c|}{ (Jiwa) } \\
\hline 1 & Denpasar & 398.025 & 395.558 & 443.775 & 376.556 & 455.941 \\
\hline 2 & Badung & 682.382 & 1.092.413 & 1.192 .129 & 1.551 .954 & 2.231.599 \\
\hline 3 & Gianyar & 1.632.069 & 1.680 .105 & 1.631.879 & 1.921.819 & 1.917.691 \\
\hline 4 & Bangli & 541.504 & 548.152 & 616.637 & 647.607 & 610.349 \\
\hline 5 & Klungkung & 239.593 & 286.648 & 298.979 & 328.313 & 372.051 \\
\hline 6 & Karangasem & 418.026 & 462.233 & 461.515 & 423.740 & 264.807 \\
\hline 7 & Buleleng & 529.616 & 743.196 & 638.147 & 775.486 & 720.921 \\
\hline 8 & Jembrana & 89.496 & 98.859 & 134.093 & 172.092 & 156.247 \\
\hline 9 & Tabanan & 3.709.389 & 4.503.653 & 4.915.516 & 4.763.558 & 4.764.579 \\
\hline
\end{tabular}

Sumber: $\quad$ http://www.disparda.baliprov.go.id/id/Statistik4 (Diakses 16 Oktober 2018)

Rumusan masalah dalam penelitian ini (1) Bagaimana pengaruh motivasi wisata spiritual terhadap customer experience pada minat berkunjung kembali wisatawan spiritual di Bali? (2) Bagaimana pengaruh service quality terhadap customer experience pada minat berkunjung kembali wisatawan spiritual di Bali? (3) Bagaimana pengaruh motivasi wisata spiritual terhadap revisit intention wisatawan spiritual di Bali? (4) Bagaimana pengaruh service quality terhadap revisit intention wisatawan spiritual di Bali? (5) Bagaimana pengaruh customer experience terhadap revisit intention wisatawan spiritual di Bali? (6) Bagaimana customer experience memediasi pengaruh motivasi wisata spiritual terhadap revisit intention wisatawan spiritual di Bali? (7) Bagaimana customer experience memediasi pengaruh service quality terhadap revisit intention wisatawan spiritual di Bali? Tujuan penelitian ini untuk (1) Menjelaskan pengaruh motivasi wisata spiritual terhadap customer experience pada minat berkunjung kembali wisatawan spiritual di Bali (2) Menjelaskan pengaruh service quality terhadap customer experience pada minat berkunjung kembali wisatawan spiritual di Bali (3) Menjelaskan pengaruh motivasi wisata spiritual terhadap revisit intention wisatawan spiritual di Bali (4) Menjelaskan pengaruh service quality terhadap revisit intention wisatawan spiritual di Bali (5) Menjelaskan pengaruh customer experience terhadap revisit intention wisatawan spiritual di Bali (6) Menjelaskan customer experience memediasi pengaruh motivasi wisata spiritual terhadap revisit intention wisatawan spiritual di Bali (7) Menjelaskan customer experience memediasi pengaruh service quality terhadap revisit intention wisatawan spiritual di Bali.

Manfaat penelitian ini yaitu diharapkan dapat memperkaya teori mengenai pariwisata spiritual di Bali, meningkatkan jumlah kunjungan ulang (revisit intention) wisatawan spiritual dengan beberapa faktor yaitu motivasi wisata spiritual, service quality, dan customer experience pada pariwisata spiritual di Bali. Dengan adanya pariwisata spiritual kiranya dapat memperkaya, meningkatkan minat berkunjung kembali wisatawan spiritual, kesejahteraan, dan bisnis di Bali.

Minat berkunjung ulang (revisit intention) diambil dari teori minat beli ulang terhadap suatu produk, sehingga dalam beberapa kategori minat berkunjung dapat diaplikasikan terhadap minat beli. Minat adalah dorongan untuk memotivasi 
seseorang melakukan tindakan (Putra dkk., 2015). Menurut Miller, Glawter, dan Primban dalam Basiya dan Rozak (2015) minat beli ulang diartikan sebagai purchase intention adalah keinginan yang kuat untuk membeli ulang, purchase intention yaitu keadaan mental seseorang yang mencerminkan rencana untuk bertindakan dalam jangka waktu tertentu. Penerapan dalam riset pada definisi purchases intention adalah pelanggan bertindakan membeli kembali pada waktu mendatang sebagai respon langsung dari perilaku paska pembelian. Purchases intention hubungannya dengan kunjungan wisatawan dalam pembelian jasa pariwisata disebut sebagai revisit intention. Pariwisata spiritual dikemukakan oleh Bali Travel News (2008) merupakan salah satu kegiatan wisata minat khusus, yakni perjalanan wisata menuju tempat - tempat suci untuk melaksanakan kegiatan spiritual berupa sembahyang, yoga, meditasi, konsentrasi, dekonsentrasi, dan istilah lainnya sesuai dengan agama dan kepercayaan masing - masing. Berdasarkan pengertian tersebut dapat diartikan bahwa revisit intention pada pariwisata spiritual adalah minat wisatawan melakukan kunjungan kembali pariwisata yang didasarkan atas kedamaian batin atau pengalaman individu. Octaviany \& Utami (2017) dan Yuniawati \& Finardi (2016) mengelompokkan dimensi revisit intention yaitu (1) Intention to recommend dan (2) Intention to revisit.

Penelitian oleh Holbrook dan Hirschmann (2015) mendefinisikan customer experience merupakan fenomena yang mengarah pada pencapaian fantasi, perasaan dan kesenangan. Akumulasi pengalaman yang dirasakan setelah mengonsumsi menimbulkan perubahan tingkat kepercayaan, kepuasan, hingga loyalitas pada produk atau servis tertentu. Berdasar pengertian sebelumnya customer experience adalah respon internal dan subjektif dari konsumen yang memerlukan kontak dengan perusahaan, baik kontak secara langsung maupun tidak langsung. Customer experience kunjungan pariwisata spiritual adalah respon internal dan subjektif dari wisatawan yang melakukan kunjungan wisata yang didasarkan atas kedamaian batin atau pengalaman individu. Schmitt dalam Kustini (2007:47) dan Salim, Catherine, \& Andreani (2014) komponen customer experience kedalam lima dimensi yaitu (1) Sense (2) Feel (3) Think (4) Act (5) Relate.

Motivasi berasal dari kata motif yang dapat diartikan sebagai kekuatan yang terdapat dalam diri individu, yang menyebabkan individu tersebut bertindak atau berbuat. Menurut Soekadijo dalam Septiawan (2016) motif adalah suatu perangsang (keinginan) dan daya penggerak (kemauan) bekerja seseorang, setiap orang mempunyai tujuan tertentu yang ingin dicapai, sedangkan motif perjalanan salah suatu pendorong atau alasan seseorang untuk mengadakan perjalanan ke suatu tempat untuk memenuhi kebutuhannya. Berdasarkan pengertian tersebut motivasi wisata spiritual adalah kekuatan yang mendorong individu untuk melakukan kegiatan didasarkan atas kedamaian batin atau pengalaman individu. Motivasi Wisata Spiritual menurut Mckercher (2016) dan Haq and Jackson (2017) mengklasifikasikan menjadi lima (1) Purposeful spiritual tourist (2) Sightseeing spiritual tourist (3) Casual spiritual tourist (4) Incidental spiritual tourist (5) Serendipitious spiritual.

Service quality menurut Kotler \& Keller (2009:49) adalah seluruh ciri serta sifat suatu produk atau pelayanan yang berpengaruh pada kemampuan untuk memuaskan kebutuhan yang dinyatakan atau yang tersirat Jadi service quality pada 
pariwisata spiritual adalah upaya untuk memuaskan wisatawan saat melakukan kegiatan yang didasarkan atas kedamaian batin atau pengalaman individu.

Service quality diukur dengan lima dimensi. Kelima dimensi itu menurut Parasuraman et al. dalam Lupiyoadi (2013:236) dan Kotler and Keller dalam Sopyan (2015) (1) Reliabilitas (reliability) (2) Daya tanggap (responsiveness) (3) Jaminan/keyakinan (assurance) (4) Empati (empathy) (5) Bukti langsung (tangibles).

Penelitian dari Narottama (2016); Banerjee (2015), Willson \& Suhud (2016); Kusuma \& Suryasih (2016); Rana (2015); Kasim (2017) menyatakan bahwa Motivasi wisata spiritual memiliki pengaruh positif signifikan terhadap customer experience pada kunjungan wisatawan spiritual di Bali.

$\mathrm{H}_{1}$ : Motivasi wisata spiritual memiliki pengaruh positif signifikan terhadap customer experience pada kunjungan wisatawan spiritual di Bali.

Penelitian oleh Wendri (2016), Sukadi \& Sanjaya (2013); dan Rana (2015) mengungkapkan Service quality memiliki pengaruh positif signifikan terhadap customer experience pada kunjungan wisatawan spiritual di Bali.

$\mathrm{H}_{2}$ : Service quality memiliki pengaruh positif signifikan terhadap customer experience pada kunjungan wisatawan spiritual di Bali.

Penelitian yang dilakukan oleh Haq et al. (2015); Willson \& Suhud (2016); Aditya, Suwena, \& Sudana (2016); Nashuddin (2016); dan Jahanian (2017) menunjukkan bahwa Motivasi wisata spiritual mempunyai pengaruh positif signifikan pada revisit intention kunjungan wisatawan spiritual di Bali.

$\mathrm{H}_{3}$ : Motivasi wisata spiritual memiliki pengaruh positif signifikan terhadap revisit intention pada kunjungan wisatawan spiritual di Bali.

Penelitian sebelumnya oleh Basiya \& Rojak (2012), Sopyan (2015); Banerjee (2015), Aditya dkk. (2016); Okayana \& Suryasih (2015); dan Rana (2015) menyebutkan Service quality memiliki pengaruh positif signifikan terhadap revisit intention pada kunjungan wisatawan spiritual di Bali.

$\mathrm{H}_{4}$ : Service quality memiliki pengaruh positif signifikan terhadap revisit intention pada kunjungan wisatawan spiritual di Bali.

Penelitian Indrawati dkk. (2013); Jauhari \& Sanjeev (2010); dan Baker \& Crompton (2000) mengungkapkan bahwa Customer experience memiliki pengaruh positif dan signifikan terhadap revisit intention pada kunjungan wisatawan spiritual di Bali.

$\mathrm{H}_{5}$ : Customer experience memiliki pengaruh positif dan signifikan terhadap revisit intention pada kunjungan wisatawan spiritual di Bali.

Penelitian dari Banerjee (2015); Willson \& Suhud (2016); dan Willson (2017) menunjukkan bahwa Customer experience memediasi pengaruh motivasi wisata spiritual terhadap revisit intention pada kunjungan wisatawan spiritual di Bali.

$\mathrm{H}_{6}$ : Customer experience memediasi pengaruh motivasi wisata spiritual terhadap revisit intention pada kunjungan wisatawan spiritual di Bali.

Penelitian yang dilakukan Bagri \& Kala (2015); Vembu et al. (2017); dan Banerjee (2015) menyebutkan Customer experience memediasi pengaruh service quality terhadap revisit intention pada kunjungan wisatawan spiritual di Bali. 
$\mathrm{H}_{7}$ : $\quad$ Customer experience memediasi pengaruh service quality terhadap revisit intention pada kunjungan wisatawan spiritual di Bali.

\section{METODE PENELITIAN}

Penelitian ini merupakan asosiatif yaitu untuk mengetahui pengaruh motivasi wisata spiritual $\left(\mathrm{X}_{1}\right)$, service quality $\left(\mathrm{X}_{2}\right)$, dan customer experience $(\mathrm{M})$ terhadap revisit intention (Y). Penelitian ini dilakukan di Kabupaten Tabanan, Gianyar, Badung, dan Karangasem. Pertimbangan memilih empat kabupaten itu karena Kabupaten Tabanan, Gianyar, dan Badung memiliki jumlah kunjungan wisatawan tertinggi di Bali (Tabel 2) dan Karangasem mem - branding dirinya menjadi "Pariwisata Spiritual". Obyek dari penelitian ini adalah motivasi wisata spiritual dan service quality yang dikaitkan dengan customer experience dan revisit intention pariwisata spiritual di Kabupaten Tabanan, Gianyar, Badung, dan Karangasem.

Populasi pada penelitian ini adalah wisatawan yang melakukan kunjungan pariwisata spiritual di salah satu Kabupaten Tabanan, Gianyar, Badung, dan Karangasem satu tahun terakhir. sampel penelitian sebanyak 100 responden, dimana 50 orang wisatawan domestik dan 50 orang wisatawan mancanegara. Dalam penelitian ini, metode penentuan sampel yang digunakan yaitu non probability sampling, teknik non-probably sampling yang dipilih adalah purposive sampling. Metode pengumpulan data dalam penelitian ini yaitu metode survei dengan menggunakan kuisioner.

Teknik analisis yang digunakan pada penelitian ini berupa statistik deskriptif, statistik inferensial, analisis jalur (path analysis), uji asumsi klasik yaang terdiri dari uji normalitas, uji multikolinieritas, dan uji heteroskedastisitas serta uji sobel.

\section{HASIL DAN PEMBAHASAN}

Hasil uji validitas instrumen penelitian menunjukkan bahwa seluruh dimensi pernyataan dalam variabel revisit intention, customer experience, motivasi wisata spiritual, dan service quality telah memenuhi syarat validitas data karena memiliki nilai pearson correlation yang lebih besar dari angka 0,30 .

Hasil uji reliabilitas instrumen pada penelitian menunjukkan keempat instrumen penelitian yaitu variabel revisit intention, customer experience, motivasi wisata spiritual, dan service quality nilai koefisien cronbach's alpha lebih dari 0,60 menunjukkan pernyataan pada kuesioner tersebut reliabel.

Berdasarkan hipotesis yang telah disusun, maka persamaan struktural dapat dirumuskan adalah sebagai berikut.

$$
\begin{aligned}
& \text { Sub-struktural } 1 \\
& \mathrm{M}=\beta_{1} \mathrm{X}_{1}+\beta_{2} \mathrm{X}_{2}+\mathrm{e}_{1}
\end{aligned}
$$

Sub-struktural 2

$$
\mathrm{Y}=\beta_{3} \mathrm{X}_{1}+\beta_{4} \mathrm{X}_{2}+\beta_{5} \mathrm{M}+\mathrm{e}_{2}
$$

Keterangan : 


\begin{tabular}{|c|c|}
\hline $\mathrm{X}_{1}$ & $=$ Motivasi wisata spiritual \\
\hline $\mathrm{X}_{2}$ & $=$ Service quality \\
\hline M & $=$ Customer experience \\
\hline $\begin{array}{l}\beta_{1}, \beta_{2}, \beta_{3}, \beta_{4}, \beta_{5} \\
\mathrm{e}\end{array}$ & $\begin{array}{l}=\text { Koefisien regresi variabel } \\
=\text { Error }\end{array}$ \\
\hline
\end{tabular}

Tabel 3.

Hasil Analisis Jalur Persamaan Regresi 1

\begin{tabular}{cccc}
\hline Model & R Square & Standardized Coefficients & \multirow{2}{*}{ Sig. } \\
\cline { 3 - 3 } & & Beta & \\
\hline Motivasi wisata spiritual & 0,667 & 0,204 & 0,011 \\
$\quad$ Service quality & & 0,667 & 0,000 \\
F statistik : 199,554 & & \\
Sig. F $\quad$ : 0,000 & & & \\
Sumber $:$ Data diolah, 2019 & &
\end{tabular}

Hasil analisis jalur substruktural 1 didapat nilai $\beta_{1}$ 0,204 artinya motivasi wisata spiritual memiliki pengaruh positif terhadap customer experience, jika faktor motivasi wisata spiritual meningkat customer experience meningkat. Nilai $\beta_{2}$ adalah sebesar 0,667 berarti service quality berpengaruh positif terhadap customer experience, artinya apabila faktor service quality meningkat maka customer experience meningkat.

Tabel 4.

Hasil Analisis Jalur Persamaan Regresi 2

\begin{tabular}{cccc}
\hline & & Standardized Coefficients & \\
\cline { 3 - 3 } Model & R Square & Beta & Sig. \\
\hline Motivasi wisata spiritual & 0,728 & 0,178 & 0,017 \\
Service quality & & 0,231 & 0,016 \\
Customer experience & & 0,523 & 0,000 \\
F statistik : 117,693 & & \\
Sig. F $\quad$ : 0,000 & &
\end{tabular}

Hasil analisis jalur substruktural 2 yang disajikan pada tabel di atas, maka nilai $\beta_{3} 0,178$ jadi motivasi wisata spiritual berpengaruh positif terhadap revisit intention, jika faktor motivasi wisata spiritual meningkat maka revisit intention meningkat. Nilai $\beta_{4} 0,231$ bermakna service quality pengaruhnya positif terhadap revisit intention, artinya service quality baik maka revisit intention meningkat. Nilai $\beta_{5}$ 0,523 memiliki arti customer experience berpengaruh positif terhadap revisit intention, dengan demikian customer experience baik maka revisit intention meningkat.

(1) Pengaruh variabel motivasi wisata spiritual $\left(\mathrm{X}_{1}\right)$ terhadap customer experience (M) $\beta_{1}=0,204$ (2) Pengaruh variabel service quality $\left(\mathrm{X}_{2}\right)$ terhadap customer experience $(\mathrm{M}) \beta_{2}=0,667$ (3) Pengaruh variabel motivasi wisata spiritual $\left(\mathrm{X}_{1}\right)$ revisit intention $(\mathrm{Y}) \beta_{3}=0,178$ (4) Pengaruh variabel service quality $\left(\mathrm{X}_{2}\right)$ 
terhadap revisit intention (Y) $\beta_{4}=0,231$ (5) Pengaruh variabel customer experience (M) terhadap revisit intention (Y) $\beta_{5}=0,523$

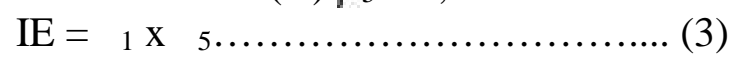

Pengaruh tidak langsung sebesar 0,107 mengindikasikan customer experience berpengaruh secara tidak langsung sebesar 10,7 persen terhadap hubungan antara motivasi wisata spiritual terhadap revisit intention.

$$
\mathrm{IE}=\beta_{2} \times \beta_{5}
$$

Pengaruh tidak langsung sebesar 0,349 menunjukkan customer experience berpengaruh secara tidak langsung sebesar 34,9 persen terhadap hubungan antara service quality terhadap revisit intention.

$$
\mathrm{TE}=\beta_{3}+\left(\beta_{1} \times \beta_{5}\right) \text {. }
$$

Pengaruh total sebesar 0,285 artinya secara total motivasi wisata spiritual mampu mempengaruhi revisit intention yang dimediasi oleh customer experience sebesar 28,5 persen.

$$
\mathrm{TE}=\beta_{4}+\left(\beta_{2} \times \beta_{5}\right)
$$

Pengaruh total sebesar 0,580 menunjukkan secara total service quality mampu mempengaruhi revisit intention yang dimediasi oleh customer experience sebesar 58 persen.

Berdasarkan model substruktural 1 dan substruktural 2 dapat disusun model diagram jalur akhir.

$$
\mathrm{e}=\sqrt{1-\mathrm{Ri}^{2}}
$$

Hasil perhitungan nilai standar eror, didapatkan hasil $\mathrm{e}_{1}$ variabel customer experience 0,577 dan $\mathrm{e}_{2}$ variabel revisit intention 0,522 .

$$
\mathrm{R}^{2} \mathrm{~m}=1-\left(\mathrm{Pe}_{1}\right)^{2}\left(\mathrm{Pe}_{2}\right)^{2}
$$

Nilai determinasi total 0,909 mempunyai arti bahwa 90,9 persen revisit intention dipengaruhi oleh motivasi wisata spiritual, service quality dan customer experience, sedangkan sisanya 9,1 persen tidak dijelaskan dalam model.

Hasil pengujian nilai koefisien signifikansi $\mathrm{F} \leq 0,05$, koefisien signifikan $0,000 \leq 0,05$, artinya $\mathrm{H}_{0}$ ditolak dan $\mathrm{H}_{1}$ diterima. Hasil ini mengindikasikan motivasi wisata spiritual, service quality, dan customer experience secara signifikan berpengaruh terhadap revisit intention. Model persamaan struktural penelitian ini melalui uji $\mathrm{F}$ sudah memenuhi syarat goodness of fit.

Nilai koefisien $\beta_{1}=0,204>0$ dari pengaruh motivasi wisata spiritual terhadap customer experience, nilai signifikansi $0,011<0,05$ menunjukkan motivasi wisata spiritual pengaruhnya positif dan signifikan pada customer experience sehingga $\mathrm{H}_{1}$ diterima dan $\mathrm{H}_{0}$ ditolak.

Pengaruh service quality terhadap customer experience memeroleh nilai koefisien $\beta_{2}=0,667>0$ dan nilai signifikansi 0,000<0,05 mengartikan Service quality berpengaruh positif dan signifikan terhadap customer experience, $\mathrm{H}_{1}$ diterima dan $\mathrm{H}_{0}$ ditolak.

Pengaruh motivasi wisata spiritual terhadap revisit intention dengan nilai koefisien $\beta_{3}=0,178>0$, nilai signifikansi sebesar $0,017<0,05$. ditarik kesimpulan bahwa motivasi wisata spiritual berpengaruh positif dan signifikan terhadap revisit intention, dengan demikian $\mathrm{H}_{1}$ diterima dan $\mathrm{H}_{0}$ ditolak. 
Pengaruh service quality terhadap revisit intention, diperoleh nilai koefisien $\beta_{4}=0,231>0$ dengan nilai signifikansi sebesar $0,016<0,05$ mengindikasikan bahwa service quality berpengaruh positif dan signifikan terhadap revisit intention, dengan demikian $\mathrm{H}_{1}$ diterima dan $\mathrm{H}_{0}$ ditolak.

Pengaruh customer experience terhadap revisit intention, didapat nilai koefisien $\beta_{5}=0,523>0$ dan nilai signifikansi sebesar $0,000<0,05$. Menunjukkan customer experience berpengaruh positif dan signifikan terhadap revisit intention, $\mathrm{H}_{1}$ diterima dan $\mathrm{H}_{0}$ ditolak.

Hasil koefisien jalur pada hipotesis penelitian dapat digambarkan pada Gambar 1. berikut.

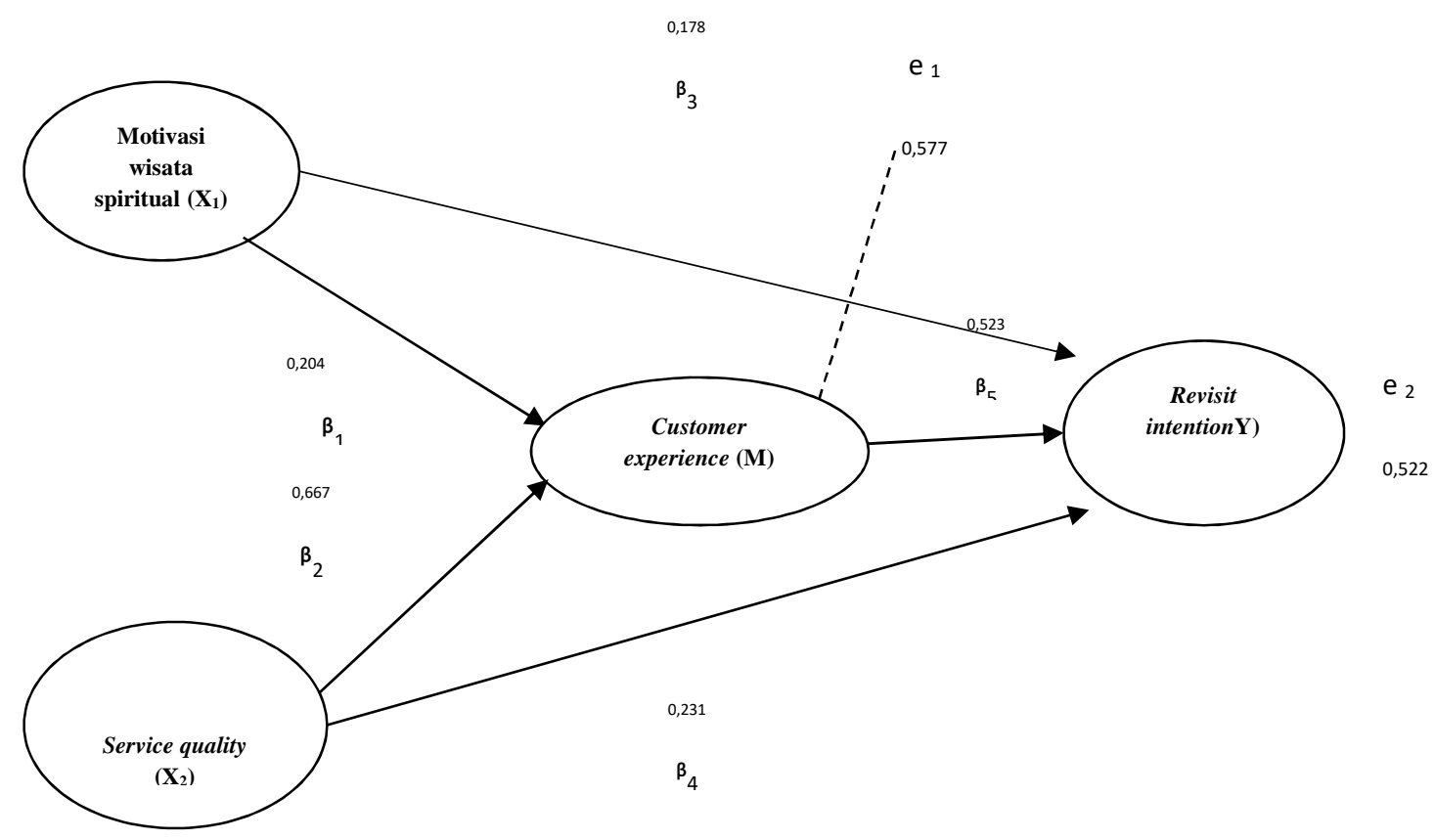

Gambar 1. Validasi Model Diagram Jalur Akhir

Keterangan :

\begin{tabular}{|c|c|}
\hline $\mathrm{Y}$ & $=$ Revisit intention \\
\hline $\mathrm{X}_{1}$ & $=$ Motivasi wisata spiritual \\
\hline$X_{2}$ & $=$ Service quality \\
\hline M & $=$ Customer experience \\
\hline $\begin{array}{l}\beta_{1}, \beta_{2}, \beta_{3}, \beta_{4}, \beta_{5} \\
\mathrm{e}\end{array}$ & $\begin{array}{l}=\text { Koefisien regresi variabel } \\
=\text { Error }\end{array}$ \\
\hline
\end{tabular}

Hasil perhitungan Tabel 5. mengindikasikan bahwa model persamaaan regresi tersebut berdistribusi normal karena nilai Asymp. Sig. (2-tailed) sebesar 0,057 dimana lebih besar dari nilai alpha yaitu 0,05 . 
Tabel 5.

Hasil Uji Normalitas Persamaan Regresi 1

\begin{tabular}{cc}
\hline & Unstandardized Residual \\
\hline $\mathrm{N}$ & 100 \\
Kolmogorov Smirnov & 1,335 \\
Asymp. Sig. (2-tailed) & 0,057 \\
\hline
\end{tabular}

Sumber: Data diolah, 2018

Tabel 6.

Hasil Uji Normalitas Persamaan Regresi 2

\begin{tabular}{cc}
\hline & Unstandardized Residual \\
\hline $\mathrm{N}$ & 100 \\
Kolmogorov Smirnov & 1,047 \\
Asymp. Sig. (2-tailed) & 0,223 \\
\hline
\end{tabular}

Sumber : Data diolah, 2018

Berdasarkan Tabel 6. menyatakan bahwa model persamaaan regresi tersebut berdistribusi normal.

Tabel 7.

Hasil Uji Multikolinieritas Persamaan Regresi 1

\begin{tabular}{lcc}
\hline \multicolumn{1}{c}{ Variabel } & Tolerance & VIF \\
\hline $\begin{array}{l}\text { Motivasi wisata spiritual } \\
\text { Service quality }\end{array}$ & 0,558 & 1,792 \\
\hline
\end{tabular}

Sumber : Data diolah, 2019

Hasil uji pada Tabel 7. mengartikan model persamaan regresi 1 bebas dari multikolinieritas.

Tabel 8.

Hasil Uji Multikolinieritas Persamaan Regresi 2

\begin{tabular}{lcc}
\hline \multicolumn{1}{c}{ Variabel } & Tolerance & VIF \\
\hline Motivasi wisata spiritual & 0,522 & 1,917 \\
Service quality & 0,319 & 3,131 \\
Customer experience & 0,333 & 3,007 \\
\hline
\end{tabular}

Sumber : Data diolah, 2019

Berdasarkan Tabel 8. menunjukkan model persamaan regresi 2 bebas dari multikolinieritas.

Hasil uji Tabel 9. menunjukkan tidak terdapat pengaruh antara variabel bebas terhadap absolut residual dengan demikian, model yang dibuat tidak mengandung gejala heteroskedastisitas.

Hasil pengujian Tabel 10. berarti tidak terdapat pengaruh antara variabel bebas terhadap absolut residual dengan demikian, model yang dibuat tidak mengandung gejala heteroskedastisitas.

$$
Z=\frac{a}{\sqrt{b^{2} \Delta_{a}^{2}+a^{2} S^{2}+\Delta_{a}^{2} S^{2}}}
$$




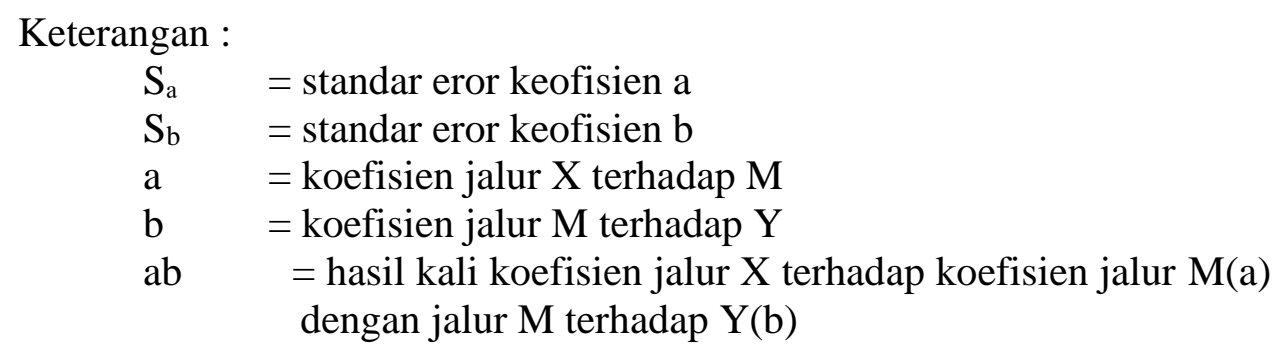

Tabel 9.

Hasil Uji Heteroskedastisitas Persamaan Regresi 1

\begin{tabular}{|c|c|c|c|c|c|c|}
\hline \multirow[t]{2}{*}{ Model } & & \multicolumn{2}{|c|}{$\begin{array}{c}\text { Unstandardized } \\
\text { Coefficients }\end{array}$} & \multirow{2}{*}{$\begin{array}{c}\begin{array}{c}\text { Standardized } \\
\text { Coefficients }\end{array} \\
\text { Beta } \\
\end{array}$} & \multirow[t]{2}{*}{$\mathbf{T}$} & \multirow[t]{2}{*}{ Sig. } \\
\hline & & B & Std. Error & & & \\
\hline \multirow[t]{3}{*}{1} & (Constant) & 0,355 & 0,199 & & 1,781 & 0,078 \\
\hline & $\begin{array}{l}\text { Motivasi wisata } \\
\text { spiritual }\end{array}$ & 0,038 & 0,063 & 0,082 & 0,611 & 0,543 \\
\hline & Service quality & $-0,64$ & 0,053 & $-0,161$ & $-1,192$ & 0,236 \\
\hline
\end{tabular}

Sumber : Data diolah, 2019

Tabel 10.

Hasil Uji Heteroskedastisitas Persamaan Regresi 2

\begin{tabular}{|c|c|c|c|c|c|c|}
\hline \multirow[t]{2}{*}{ Model } & & \multicolumn{2}{|c|}{$\begin{array}{c}\text { Unstandardized } \\
\text { Coefficients }\end{array}$} & \multirow{2}{*}{$\begin{array}{c}\begin{array}{c}\text { Standardized } \\
\text { Coefficients }\end{array} \\
\text { Beta } \\
\end{array}$} & \multirow[t]{2}{*}{$\mathbf{T}$} & \multirow[t]{2}{*}{ Sig. } \\
\hline & & B & Std. Error & & & \\
\hline \multirow[t]{4}{*}{1} & (Constant) & 0,705 & 0,186 & & 3,781 & 0,000 \\
\hline & $\begin{array}{l}\text { Motivasi wisata } \\
\text { spiritual }\end{array}$ & $-0,061$ & 0,059 & $-0,141$ & $-1,028$ & 0,307 \\
\hline & Service quality & $-0,060$ & 0,064 & $-0,165$ & $-0,937$ & 0,351 \\
\hline & $\begin{array}{l}\text { Customer } \\
\text { experience }\end{array}$ & 0,024 & 0,069 & 0,059 & 0,345 & 0,731 \\
\hline a. & ependent Variabe & sres 2 & & & & \\
\hline
\end{tabular}

Sumber: Data diolah, 2019

Hasil perhitungan nilai z hitung 2,1393 artinya lebih besar dari nilai z tabel yaitu 1,96 memiliki arti customer experience secara positif dan signifikan memediasi pengaruh Motivasi wisata spiritual terhadap revisit intention. Hasil perhitungan nilai $\mathrm{z}$ hitung 4,3034 berarti customer experience secara positif dan signifikan memediasi pengaruh service quality terhadap revisit intention.

Hasil analisis pengaruh Motivasi wisata spiritual terhadap customer experience nilai koefisien $\beta_{1} 0,204>0$ dengan nilai signifikansi sebesar $0,011<$ 0,05 Motivasi wisata spiritual pengaruhnya positif dan signifikan terhadap customer experience, Motivasi wisata spiritual wisatawan yang tinggi dalam melakukan kunjungan pariwisata spiritual maka meningkat pula customer experience atau pengalaman yang dirasakan wisatawan tersebut.

Hasil penelitian ini sesuai dengan penelitian yang dilakukan oleh Narottama (2016); Banerjee (2015); Willson \& Suhud (2016); Kusuma \& Suryasih (2016); 
Rana (2015) dan Kasim (2017) menyatakan bahwa Motivasi wisata spiritual memiliki pengaruh positif signifikan terhadap customer experience pada kunjungan wisatawan spiritual di Bali.

Berdasarkan hasil analisis pengaruh service quality terhadap customer experience, didapat nilai koefisien $\beta_{1}$ sebesar 0,667 dengan nilai signifikansi sebesar 0,000. Nilai koefisien $\beta_{1}>0$ dan nilai signifikansi $<0,05$ sehingga $\mathrm{H}_{1}$ diterima dan $\mathrm{H}_{0}$ ditolak, menyatkan service quality pengaruhnya positif dan signifikan pada customer experience, semakin baik service quality atau kualitas pelayanan yang diberikan kepada wisatawan dalam melakukan kunjungan pariwisata spiritual maka meningkat customer experience atau pengalaman yang dirasakan wisatawan tersebut.

Hasil penelitian ini serah dengan dengan penelitian yang dilakukan oleh Wendri (2016); Sukadi. \& Sanjaya (2013); dan Rana (2015) mengungkapkan Service quality memiliki pengaruh positif signifikan terhadap customer experience pada kunjungan wisatawan spiritual di Bali.

Berdasarkan hasil analisis pengaruh spiritual motivation terhadap revisit intention, hasil nilai koefisien $\beta_{3}$ sebesar $0,178>0$ dengan nilai signifikansi sebesar $0,017<0,05$ sehingga $\mathrm{H}_{1}$ diterima dan $\mathrm{H}_{0}$ ditolak, motivasi wisata spiritual pengaruhnya positif dan signifikan terhadap revisit intention. Berarti, tingginya motivasi wisata spiritual wisatawan dalam melakukan kunjungan pariwisata spiritual maka akan meningkatkan revisit intention atau minat berkunjung ulang wisatawan tersebut.

Hasil ini sama dengan penelitian Haq et al. (2015); Willson \& Suhud (2016); Aditya et al. (2016); Nashuddin (2016); dan Jahanian (2017) menunjukkan bahwa Motivasi wisata spiritual memiliki pengaruh positif signifikan terhadap revisit intention pada kunjungan wisatawan spiritual di Bali.

Hasil analisis pengaruh service quality terhadap revisit intention, diperoleh hasil nilai koefisien $\beta_{4}$ sebesar 0,231>0 dengan nilai signifikansi sebesar $0,016<$ 0,05 berarti bahwa service quality pengaruhnya positif dan signifikan terhadap revisit intention. Jadi, semakin baik service quality atau kualitas layanan yang diberikana pada wisatawan dalam melakukan kunjungan pariwisata spiritual maka semakin meningkat revisit intention atau minat berkunjung ulang wisatawan tersebut. Hasil dari penelitian ini sesuai yang dilakukan oleh Basiya \& Rojak (2012); Sopyan (2015); Banerjee (2015); Aditya et al. (2016); Okayana \& Suryasih (2015); dan Rana (2015) menyatakan bahwa Service quality memiliki pengaruh positif signifikan terhadap revisit intention pada kunjungan wisatawan spiritual di Bali.

Berdasarkan hasil analisis pengaruh customer experience terhadap revisit intention, hasil nilai koefisien $\beta_{5}$ sebesar $0,523>0$ dengan nilai signifikansi sebesar $0,000<0,05$ mengindikasikan customer experience berpengaruh positif dan signifikan terhadap revisit intention. Itu berarti, makin tinggi customer experience atau pengalaman yang dirasakan oleh wisatawan saat melakukan kunjungan pariwisata spiritual di Bali maka akan semakin mendorong meningkatkan minat berkunjung kembali ke destinasi pariwisata apiritual di Bali.

Hasil ini sejalan dengan Indrawati dkk. (2013); Jauhari \& Sanjeev (2010); dan Baker \& Crompton (2000) mengungkapkan bahwa Customer experience 
memiliki pengaruh positif dan signifikan terhadap revisit intention pada kunjungan wisatawan spiritual di Bali.

Hasil uji pengaruh langsung variabel motivasi wisata spiritual terhadap revisit intention awalnya bernilai 0,178 , setelah ada customer experience sebagai mediasi, nilai pengaruh spiritual motivation pada revisit intention naik menjadi sebesar 0,285, ini menunjukkan customer experience memediasi pengaruh motivasi wisata spiritual terhadap revisit intention secara parsial. Hasil uji sobel menunjukkan bahwa customer experience secara positif dan signifikan memediasi pengaruh motivasi wisata spiritual terhadap revisit intention. Nilai uji sobel pengaruh motivasi wisata spiritual terhadap revisit intention melalui customer experience adalah sebesar $Z=2,1393>1,96$. Nilai uji sobel di atas menunjukkan bahwa customer experience mampu memediasi pengaruh otivasi wisata spiritual terhadap revisit intention secara positif dan signifikan.

Hasil penelitian ini searah yang dilakukan Banerjee (2015); Willson \& Suhud (2016); dan Willson (2017) menunjukkan bahwa Customer experience memediasi pengaruh motivasi wisata spiritual terhadap revisit intention pada kunjungan wisatawan spiritual di Bali.

Hasil uji pengaruh langsung variabel service quality terhadap revisit intention awalnya bernilai 0,231 , setelah adanya customer experience sebagai variabel mediasi, nilai pada pengaruh service quality terhadap revisit intention meningkat menjadi sebesar 0,580. Hasil ini berarti bahwa customer experience memediasi pengaruh service quality terhadap revisit intention secara parsial. Hasil uji sobel menyatakan customer experience secara positif dan signifikan memediasi pengaruh service quality terhadap revisit intention. Nilai uji sobel pengaruh service quality terhadap revisit intention melalui customer experience adalah sebesar $\mathrm{Z}=4,3034$ > 1,96. Nilai uji sobel di atas menunjukkan bahwa customer experience mampu memediasi pengaruh service quality terhadap revisit intention secara positif dan signifikan.

Hasil penelitian ini sejalan yang dilakukan oleh Bagri \& Kala (2015); Vembu et al. (2017); dan Banerjee (2015) mengungkapkan Customer experience memediasi pengaruh service quality terhadap revisit intention pada kunjungan wisatawan spiritual di Bali.

Implikasi hasil penelitian ini mencakup dua hal yaitu, implikasi teoritis dan implikasi praktis. Implikasi teoritis berhubungan dengan kontribusinya bagi perkembangan teori - teori mengenai variabel motivasi wisata spiritual, service quality, customer experience, dan revisit intention. Implikasi praktis berkaitan dengan kontribusi penelitian pada stakeholders pariwisata spiritual dalam upaya meningkatkan jumlah kunjungan wisatawan spiritual dengan beberapa faktor yaitu revisit intention, motivasi wisata spiritual, service quality, dan customer experience, pada pariwisata spiritual di Bali. Adanya pariwisata spiritual diharapkan dapat memperkaya, meningkatkan jumlah kunjungan wisatawan, kesejahteraan, dan bisnis di Bali.

Beberapa keterbatasan penelitian yang dapat ditarik dari penelitian ini adalah (1) Ketersediaan data penelitian terkait proporsi sebaran kunjungan wisatawan spiritual di Bali (2) Ruang lingkup penelitian yang hanya dilakukan di empat Kabupaten yaitu, Tabanan, Badung, Gianyar, dan Karangasem dengan jumlah 
responden 100, 50 orang wisatawan responden domestik dan 50 orang wisatawan mancanegara, sehingga hasil dari penelitian ini tidak dapat digeneralisasi untuk wisatawan yang berada diluar ke - empat kabupaten tersebut (3) Penelitian ini hanya dilakukan dalam titik waktu tertentu (cross section) sedangkan lingkungan setiap saat dapat berubah, sehingga penelitian ini penting untuk dilakukan kembali di masa mendatang (4) Jumlah variabel yang diteliti dalam penelitijan ini hanya terbatas pada variabel motivasi wisata spiritual, service quality, customer experience, dan revisit intention.

\section{SIMPULAN}

Simpulan yang dapat diberikan berdasarkan pembahasan hasil penelitian yang telah dilakukan ialah (1) Motivasi wisata spiritual berpengaruh positif dan signifikan terhadap customer experience. Hasil ini berarti, semakin tinggi motivasi wisata spiritual wisatawan dalam melakukan kunjungan pariwisata spiritual maka semakin meningkat customer experience atau pengalaman yang dirasakan wisatawan tersebut (2) Service quality berpengaruh positif dan signifikan terhadap customer experience. Hasil ini berarti, semakin baik service quality atau kualitas pelayanan yang diberikan kepada wisatawan dalam melakukan kunjungan pariwisata spiritual maka semakin meningkat customer experience atau pengalaman yang dirasakan wisatawan tersebut (3) Motivasi wisata spiritual berpengaruh positif dan signifikan terhadap revisit intention. Hasil ini berarti, semakin tinggi motivasi wisata spiritual wisatawan dalam melakukan kunjungan pariwisata spiritual maka semakin meningkat revisit intention atau minat berkunjung ulang wisatawan tersebut (4) Service quality berpengaruh positif dan signifikan terhadap revisit intention. Hasil ini berarti, semakin baik service quality atau kualitas layanan yang diberikana pada wisatawan dalam melakukan kunjungan pariwisata spiritual maka semakin meningkat revisit intention atau minat berkunjung ulang wisatawan tersebut (5) Customer experience berpengaruh positif dan signifikan terhadap revisit intention.

Hasil ini berarti, semakin tinggi customer experience atau kepercayaan yang dirasakan oleh wisatawan saat melakukan kunjungan pariwisata spiritual di Bali maka akan semakin mendorong meningkatnya minat berkunjung kembali ke destinasi pariwisata apiritual di Bali (6) Customer experience secara positif dan signifikan memediasi pengaruh motivasi wisata spiritual terhadap revisit intention. Hasil ini berarti, motivasi wisata spiritual sebelumnya yang akan menimbulkan pengalaman pada wisatawan. Wisatawan mendapat pengalaman pada saat melakukan aktivitas pariwisata spiritual di Bali berpotensi untuk memiliki minat berkunjung kembali ke destinasi pariwisata spiritual sehingga dapat menimbulkan kunjungan kembali pada destinasi pariwisata spiritual di Bali (7) Customer experience secara positif dan signifikan memediasi pengaruh service quality terhadap revisit intention. Hasil ini berarti, Kualitas layanan sebelumnya yang akan menimbulkan pengalaman pada wisatawan. wisatawan mendapat pengalaman pada saat melakukan aktivitas pariwisata spiritual di Bali berpotensi untuk memiliki minat berkunjung kembali ke destinasi pariwisata spiritual sehingga dapat menimbulkan kunjungan kembali pada destinasi pariwisata spiritual di Bali. 
Saran yang dapat diberikan berdasarkan simpulan yang dipaparkan kepada stakeholders dan penelitian selanjutnya, yaitu (1) Stakeholders diharapkan mampu mendorong revisit intention terutama pada minat wisatawan melakukan kunjungan kembali pada destinasi pariwisata spiritual di Bali karena pada deskripsi jawaban responden mengenai varibel revisit intention dimensi intention to revisit memiliki rata - rata nilai terendah guna meningkatkan minat kunjungan kembali wisatawan spiritual di Bali (2) Stakeholders diharapkan mampu meningkatkan customer experience terutama pada pengalaman wisatawan yang berhubungan dengan kemanfaatan fisik karena pada deskripsi jawaban responden mengenai variabel customer experience dimensi act memiliki rata - rata nilai terendah guna meningkatkan minat kunjungan kembali wisatawan spiritual di Bali (3) Stakeholders diharapkan mampu menangkap peluang motivasi wisata spiritual wisatawan terutama purposeful spiritual tourist dan sightseeing spiritual tourist karena pada deskripsi jawaban responden mengenai variabel motivasi wisata spiritual dimensi purposeful spiritual tourist dan sightseeing spiritual tourist memiliki nilai terendah guna meningkatkan minat kunjungan kembali wisatawan spiritual di Bali (4) Stakeholders diharapkan mampu memberikan layanan yang berkualitas terutaman pada dimensi assurance karena pada deskripsi jawaban responden mengenai variabel service quality dimensi assurance memiliki rata - rata nilai terendah guna meningkatkan minat kunjungan kembali wisatawan spiritual di Bali (5) Peneliti selanjutnya diharapkan memperluas ruang lingkup penelitian, menambahkan data real terkait proporsi sebaran kunjungan wisatawan spiritual di Bali, menambah variabel penelitian seperti variabel kepuasan, hospitality, dan melakukan penelitian secara periodik (time series) agar diperoleh hasil penelitian yang riil dan aktual.

\section{REFERENSI}

Aditya, I. W. P., Suwena, I. K., \& Sudana, I. P. (2016). Studi Eksplorasi Pariwisata Spiritual di Sentra Pariwisata Ubud, Gianyar (Studi Kasus di Ubud Bodywork Centre dan Yoga Barn). Jurnal IPTA Fakultas Pariwisata UNUD, 4(1), 26 31.

Bagri, S. C., \& Kala, D. (2015). Tourists' Satisfaction at Trijuginarayan: An Emerging Spiritual and Adventure Tourist Destination in Garhwal Himalaya India. Original Scientific Paper Turizam, 9(4), 165-182.

Baker, D. A., \& Crompton, J. L. (2000). Quality, Satisfaction, And Behaviour Intentions. Annuals Of Tourism Research, 27(3), 785 - 804.

Banerjee, M. (2015). Spiritual Tourism: A Tool For Socio-Cultural And Sustainable Development. International Journal Of Science And Research Department Of Hotel Management MJP Rohilkhand University, 4(10), 1244 - 1249. 
Basiya, R., \& Rojak, H. (2012). Kualitas Daya Tarik Wisata, Kepuasan, Dan Niat Kunjungan Kembali Wisatawan Mancanegara Di Jawa Tengah. Semarang.

Haq, F., Wong, H. Y., \& Jackson, J. (2015). Applying Ansoff's Growth Strategy Matrix To Consumer Segments And Typologies In Spiritual Tourism. Journal Of Business And Informatics Central Queensland University, 1(1), $1-12$.

Indrawati, Y., Sudana, I. P., Mahadewi, N. P. E., Mananda, I. B. S., \& Ariani, N. M. (2013). Pengembangan Manajemen Daya Tarik Wisata Berbasis Quality Experiences Di Objek Wisata Alas Kedaton Tabanan. Udayana Mengabdi, 12(2), $90-93$.

Jahanian, M. (2017). Futures Studies Of Tourism With A Spirituality Perspective. International Journal Of Tourism And Spirituality University Of Science And Culture, 2(1), $24-39$.

Jauhari, V., \& Sanjeev, G. M. (2010). Managing Customer Experience For Spiritual And Cultural Tourism: An Overview. Worldwide Hospitality And Tourism Themes Institute For International Management And Technolog Gurgaon, 2(5), $467-476$.

Kasim, A. (2017). The Spirituality Of Green Travel And Tourism. International Journal Of Tourism And Spirituality International Journal Of Tourism And Spirituality University Of Science And Culture, 1(1), 116 - 124.

Kotler, P., \& Keller, K. L. (2009). Marketing Management. New Jersey: Pearson Prentice Hall International.

Kustini. (2007). Penerapan Experiential Marketing. Jurnal Riset Ekonomi Dan Bisnis, 7(1), 44-57.

Kusuma, I. G. A. R. D., \& Suryasih, I. A. (2016). Aktivitas Wisata Spiritual Dan Motivasi Berwisata Di Daya Tarik Wisata Tanah Lot Kabupaten Tabanan. Jurnal Destinasi Pariwisata Fakultas Pariwisata, Universitas Udayana, 4(2), $118-122$.

Lupiyoadi, R. (2013). Manajemen Pemasaran Jasa Berbasis Kompetensi (Edisi 3). Jakarta: Salemba Empat.

Narottama, N. (2016). Spiritual Tourism: A Case Study Of Foreigners' Participation In The Pitrayajna Ceremony In The Desa Pakraman Of Muncan, Selat, Karangasem, Bali. E-Journal Of Tourism Bali International Tourism Institute, 3(1), 33 - 44. 
Nashuddin. (2016). The Management Of Muslim Spiritual Tourism In Lombok, Indonesia (Opportunities And Challenges). Journal Of Indonesian Islam State Institute Of Islamic Studies (IAIN) Mataram, 10(2), 213 - 236. https://doi.org/10.15642/JIIS.2016.10.2.213-236

Octaviany, V., \& Utami, D. D. (2017). Revisit Intention Wisatawan Di Taman Tematik Kota Bandung. Tourism And Hospitality Essentials (THE) Journal, $7(1), 41-46$.

Okayana, I. G. A. P. A., \& Suryasih, I. A. (2015). Identifikasi Potensi "Pasiraman Pura Dalem Pingit Lan Pura Kusti” Di Desa Sebatu, Gianyar Sebagai Wisata Spiritual. Jurnal Destinasi Pariwisata Fakultas Pariwisata Universitas Udayana, 3(2), 1 - 5 .

Putra, S. B., Kumadji, S., \& Hidayat, K. (2015). Pengaruh Citra Perusahaan Terhadap Minat Berkunjung Ulang Dan Keputusan Berkunjung (Survei Pada Pengunjung Taman Rekreasi PT. Selecta, Kota Batu, Jawa Timur). Universitas Brawijaya.

Rana, V. (2015). Motives And Experiences Of Foreign (Yoga \& Spiritual) Tourist Visiting Rishikesh. International Journal For Research In Education (IJRE), $4(1), 2347-5412$.

Salim, K. F., Catherine, \& Andreani, F. (2014). Pengaruh Customer Experience Dan Kepercayaan Terhadap Kepuasan Konsumen Di Tx Travel Klampis. EJurnal Manajemen Perhotelan Universitas Kristen Petra, 1(2), 322 - 320.

Septiawan, F. (2016). Motivasi Wisatawan Berkunjung Ke Taman Merdeka Metro Tahun 2016. Jurnal Keguruan Dan Ilmu Pendidikan Universitas Lampung, $1(2), 17-26$.

Sopyan, I. W. (2015). Anteseden Minat Berkunjung Ulang (Studi Pada Cagar Budaya Bedung Lawang Sewu Semarang). Jurnal Ekonomi Universitas Diponegoro, 4(2), 1-9.

Sukaatmadja, I. P. G., Wardana, M., Purbawangsa, I. B. A., \& Rahanatha, G. B. (2017). Pariwisata Spiritual : Berbasis Event - Event Upacara Agama Hindu. Prosiding Seminar Nasional AIMI. Jambi.

Sukadi., S., \& Sanjaya. (2013). Pengembangan Potensi Pariwisata Spiritual Berbasis Masyarakat Lokal Di Bali. Jurnal Ilmu Sosial Dan Humaniora Universitas Pendidikan Ganesha, 2(1), 150 - 157.

Vembu, N. R., Sivakumar, M., Srinivasan, S., Veeramani, S., Senthilvel, S., \& Vanitha, R. (2017). Spiritual Tourism And Identification Of Satisfaction Among Pilgrims - An Empirical Study. International Journal Of Economic 
Research, 14(4), $497-510$.

Wardaya, Y. (2015). Pengaruh Desain Produk, Keragaman Produk, dan Promosi Terhadap Kepuasan Konsumen Charger City Clothing. E-Jurnal Manajemen Udayana, 1(4), 1-20.

Wendri, I. G. M. (2016). Kajian Motivasi Penawaran Pariwisata Spiritual Bali Ke Depan. Jurnal Sosial Dan Humaniora Politeknik Negeri Bali, 6(1), 66 - 77.

Willson, G. (2017). Spiritual Awakening Leading To A Search For Meaning Through Travel. International Journal Of Tourism And Spirituality University Of Science And Culture, 2(1), 10 - 23.

Willson, G., \& Suhud, U. (2016). The Interconnectedness Of Personal Spirituality And Tourism Experiences. Journal Of Tourism Challenges And Trends, 9(1), $93-108$.

Yuniawati, Y., \& Finardi, A. D. I. (2016). Pengaruh Customer Experience Terhadap Revisit Intention Di Taman Wisata Alam Gunung Tangkuban Perahu. Tourism And Hospitality Essentials (THE) Journal, 6(1), 983 - 994. 